\title{
Dentin penetrability evaluation of three different dyes in root-end cavities filled with mineral trioxide aggregate (MTA)
}

\section{Avaliação da penetração dentinária de três diferentes corantes em retrocavidades obturadas com agregado trióxido mineral (MTA)}

\author{
Beatriz Farias Vogt* \\ Cristina Braga Xavier** \\ Flávio Fernando Demarco*** \\ Marcio Schüler Padilha****
}

\begin{abstract}
The purpose of this study was to evaluate the penetration of three dyes in MTA root-end fillings. In 30 single-rooted teeth, cavities for retrofilling were prepared with an ultrasound appliance and filled with MTA. The specimens were randomly assigned to three groups $(\mathrm{n}=10)$ and immersed in the following solutions: $2 \%$ methylene blue (MET), 50\% silver nitrate (NIT) and 0.2\% rhodamine B (ROD). Two transversal slices (1 mm) of the retrofilling region were obtained and evaluated using the Image Tool 3.0 software to obtain a quantitative evaluation (in $\mathrm{mm}^{2}$ ) of the dye penetration around the retrofillings. Data were submitted to statistical analysis using Student's $t$-test. The lowest degree of dye penetration was observed for the NIT group, in both slices $(p<0.05)$. Dye penetration was significantly larger in the ROD group when compared to the NIT group, in both slices ( $<0.05)$, and to the MET group, only in slice $1(\mathrm{p}<0.05)$. Within the limitations of this study, it was concluded that the choice of dye could influence the penetration evaluation in root-end filling studies, and that the NIT had the lowest penetration capacity in the apical dentine.
\end{abstract}

DESCRIPTORS: Dental leakage; Dyes; Retrograde obturation.

RESUMO: A proposta deste trabalho foi avaliar a penetração de três corantes em retrocavidades obturadas com MTA. As retrocavidades foram confeccionadas com aparelho de ultra-som em 30 dentes unirradiculares e obturadas com MTA. Os espécimes foram divididos aleatoriamente em três grupos $(\mathrm{n}=10)$ e imersos nas seguintes soluções corantes: azul de metileno a $2 \%$ (MET), nitrato de prata a 50\% (NIT) e rodamina B a 0,2\% (ROD). Duas fatias transversais $(1 \mathrm{~mm})$ da região retrobturada foram obtidas e avaliadas através do software Image Tool 3.0, objetivando quantificar a área $\left(\mathrm{em}^{\left.\mathrm{mm}^{2}\right)}\right.$ de penetração do corante ao redor das retrobturações. Os dados foram submetidos à análise estatística, utilizando o teste $t$ de Student. A menor área de penetração foi observada no grupo NIT, nas duas fatias $(\mathrm{p}<0.05)$. A penetração de corante foi significativamente maior no grupo ROD quando comparado ao grupo NIT, nas duas fatias $(\mathrm{p}<0.05)$, e ao grupo MET, somente na fatia 1 ( $\mathrm{p}<0.05)$. Dentro das limitações desta pesquisa, concluiu-se que a escolha da solução corante pode influenciar a avaliação da penetração em estudos sobre retrobturações e que o grupo NIT teve a menor capacidade de penetração na dentina apical.

DESCRITORES: Infiltração dentária; Tinturas; Obturação retrógrada.

\section{INTRODUCTION}

Endodontic surgery is an alternative to avoid dental extractions when the endodontic therapy and the retreatment of the root canal has failed or is impossible to be made ${ }^{29}$. The capacity of sealing the apical region is an important aspect when choosing a root-end filling material, aiming to prevent microleakage, i.e., the passage of bacteria, fluid, molecules or ions between the cavity wall and the filling material ${ }^{12}$. The obtaining of a hermetic seal has been a concern regarding rootend therapy, leading to the development of new materials and techniques that allow the complete and three-dimensional sealing of the root canal system. Dye penetration tests, bacterial leakage, and fluid filtration are some methodological approaches used to evaluate apical sealing; however, contradictory findings are still observed in the literature ${ }^{4,6,24,28,29}$.

\footnotetext{
* Department of Oral and Maxillofacial Surgery; **DDS, Department of Oral and Maxillofacial Surgery; ${ }^{* * * D D S, ~ D e p a r t m e n t ~ o f ~}$ Dentistry; ${ }^{* * *}$ Dental School - Federal University of Pelotas.
} 
Vogt BF, Xavier CB, Demarco FF, Padilha MS. Dentin penetrability evaluation of three different dyes in root-end cavities filled with mineral trioxide aggregate (MTA). Braz Oral Res 2006;20(2):132-6.

Innumerable root-end filling materials are available on the market to be used in endodontic surgery, but none of them has yet presented the characteristics of an ideal material ${ }^{23}$. In 1993, Torabinejad et al..$^{25}$ evaluated in vitro the apical sealing capacity of a new material, the mineral trioxide aggregate (MTA). MTA is a dental cement consisting of tricalcium silicate, tricalcium oxide, silicate oxide, and other mineral oxides that are responsible for the physical and chemical material properties. MTA has demonstrated better sealing ability than some other commonly used dental materials ${ }^{14,29}$.

Despite the large use of microleakage tests, several different methodological approaches can influence the test ${ }^{16}$. Various dyes such as methylene blue, silver nitrate, rhodamine and fuchsine have been proposed to be used in leakage tests and the specific chemical and physical proprieties of each substance could interfere with the penetration readings, producing different study results ${ }^{14,16}$.

Methylene blue has already been evaluated in several concentrations and immersion times ${ }^{1,7,11}$, $13,17,20,22,26$, being the dye most commonly used. Nevertheless, some dental materials have the property of diminishing the color stability of methylene blue, thus reducing its optical density. This was verified by Wu et al. ${ }^{27}$ (1998), when they observed that MTA had caused one of the highest rates of alteration of the substance, questioning the feasibility of using that dye for leakage tests.

According to Azoubel, Veeck ${ }^{3}$ (1998), rhodamine B could be applied in studies of dye penetration because it has smaller particles, presenting a great diffusibility in dentinal tubules, and because it is easily visualized.

Silver nitrate is a tracing substance used in studies of nanoleakage, the leakage that occurs within the porous region of the hybrid layer, even though in the absence of gaps at the adhesive interface ${ }^{18}$. Xavier et al. ${ }^{29}$ (2005) observed penetration of $50 \%$ silver nitrate within the MTA and in the dentinal walls, but they were not able to find the reason for this observation.

The different methodological approaches for leakage tests regarding the type of dye employed in root-end filling studies provide controversial results and the best tracer substance remains to be determined.

The aim of this study was to evaluate the penetrability of three dyes (rhodamine, silver nitrate and methylene blue) in root-end cavities filled with MTA.

\section{MATERIAL AND METHODS}

The research protocol had the approval of the Ethics in Research Committee (School of Dentistry, Federal University of Pelotas). Thirty permanent single-rooted teeth were selected, regardless of their conditions at extraction time.

The teeth were kept immersed in saline solution for three months. After that, scaling of the remaining periodontal ligament was performed and the crowns were sectioned transversally next to the cementum-enamel junction with a diamond saw (KG Sorensen Ltda., São Paulo, SP, Brazil), under copious water irrigation. Each specimen was standardized with $15 \mathrm{~mm}$ in height.

The specimens were instrumented until file \#40 (Flexofile, Moyco Union Broach, USA) following the step-back technique, and were then irrigated with $20 \mathrm{ml}$ of $0.5 \%$ sodium hypochlorite solution (Rio Química Ltda., São José do Rio Preto, SP, Brazil). The root canals were dried with absorbent paper points (Endo Points Ltda., Paraíba do Sul, RJ, Brazil) and obturated through the lateral condensing technique with gutta-percha and Endofill (Dentsply, Petrópolis, RJ, Brazil). At that moment, all the dental elements were submitted to radiography in order to verify the obturation quality.

With a diamond disk (KG Sorensen Ltda., São Paulo, SP, Brazil), the roots were then submitted to a root-end resection at a distance of $3 \mathrm{~mm}$ from the dental apex, at an angle of $90^{\circ}$ with the root, under constant irrigation with saline solution.

Following the anatomical orientation of the root canal, $3 \mathrm{~mm}$-deep root-end cavities were prepared using an S12/90D ultrasonic tip (Gnatus, Ribeirão Preto, SP, Brazil), under water cooling. Then, the entire external root surfaces of the specimens were covered with two-coats of nail polish (Niasi, Taboão da Serra, SP, Brazil), except for the sectioned surface.

The root-end cavities were filled with MTA (Angelus - Soluções Odontológicas, Londrina, PR, Brazil), according to the manufacturer's instructions. Soon after the root-end fillings were made, the roots were immediately suspended in a glass recipient through a steel wire device fixed on the coronal region, allowing the immersion of the apical portion into the dye solution.

The 30 specimens were randomly assigned to three different groups $(\mathrm{n}=10)$ :

- MET Group - specimens were immersed in a $2 \%$ methylene blue solution ( $\mathrm{pH}$ 7) (School of Chemistry, UFPel, Pelotas, RS, Brazil). 
Vogt BF, Xavier CB, Demarco FF, Padilha MS. Dentin penetrability evaluation of three different dyes in root-end cavities filled with mineral trioxide aggregate (MTA). Braz Oral Res 2006;20(2):132-6.

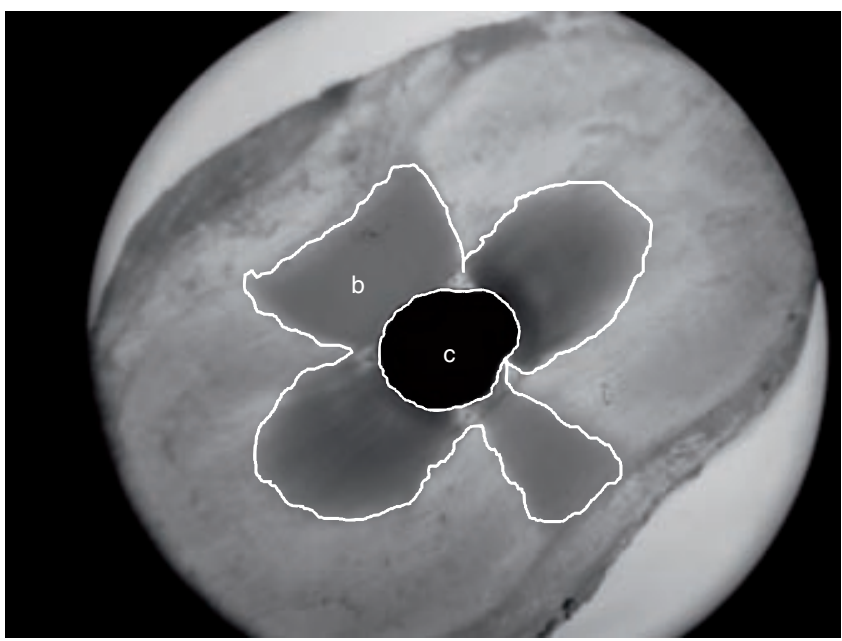

FIGURE 1 - Determination of $\mathbf{b}$ (area corresponding to the dye penetration and to the retrocavity); determination of $\mathbf{c}$ (area corresponding to the retrocavity).

- NIT Group - specimens were immersed in a $50 \%$ silver nitrate aqueous solution $(\mathrm{pH} \mathrm{3)}$ (School of Chemistry, UFPel, Pelotas, RS, Brazil).

- ROD Group - specimens were immersed in a $0.2 \%$ rhodamine B solution ( $\mathrm{pH} 7$ ) (School of Chemistry, UFPel, Pelotas, RS, Brazil).

The MET and ROD groups were stored at $37^{\circ}$ for 24 hours. After that, the specimens were washed in running water for the same time. Specimens of the NIT group were immersed into the solution during 2 hours in the absence of light, under room temperature. Then, they were also washed in running water and immersed into another vial with photo-developing solution (Decktol, Kodak, São José dos Campos, SP, Brazil) for 12 hours, under continuous illumination, aiming at the reduction and precipitation of silver ions.

In each specimen the apical portion was transversally sectioned through the root-end cavity, producing two slices of one millimeter each, using a diamond saw (KG Sorensen Ltda., São Paulo, SP, Brazil) under continuous irrigation with saline solution. The coronal surfaces of slice 1 (more apical) and slide 2 (more coronal) from each specimen were digitized with an image capture system connected to a stereoscopic microscope (Impac, Tokyo, Japan), under magnification (25 X). The total area of dye penetration was measured quantitatively (in $\mathrm{mm}^{2}$ ) with the Image Tool 3.0 software (San Antonio Dental School, University of Texas Health Science Center, TX, USA).

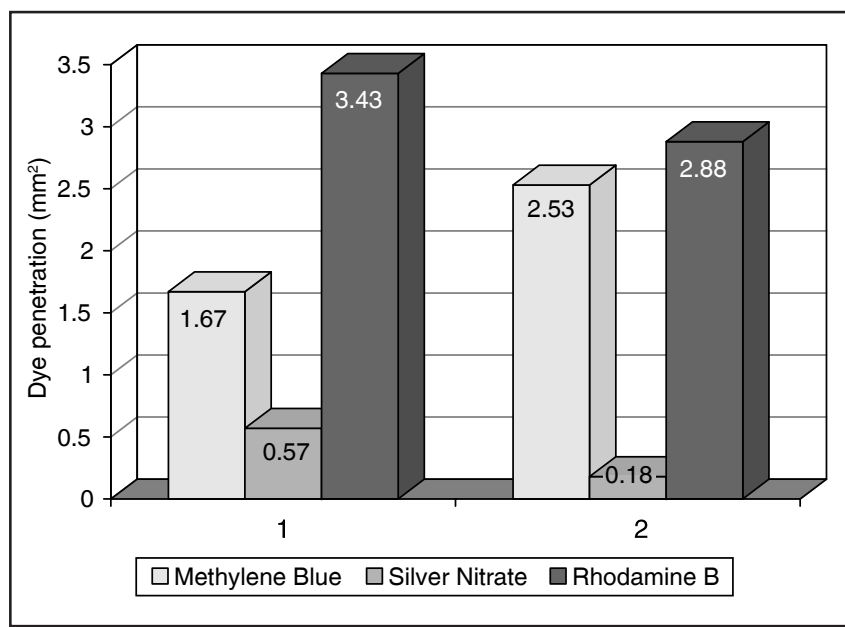

GRAPH 1 - Mean values (in $\mathrm{mm}^{2}$ ) of dye penetration for the different tracer solutions, obtained in slices 1 and 2.

The dye penetration measurement methodology is demonstrated in Figure 1. Briefly, the total amount of dye penetration including the root-end filling was determined (b). Then, the surface area of the root-end filling was determined (c) and the dye penetration was the result of $b$ minus $c$. The measurements were made by two calibrated examiners.

The data were submitted to statistical analysis using Student's $t$-test.

\section{RESULTS}

The mean values of dye penetration for each dye solution in each one of the slices are exhibited in Graph 1.

In both slices, the NIT group (silver nitrate) disclosed the lowest penetration when compared to the other groups $(\mathrm{p}<0.05)$. The MET group (methylene blue) showed lower penetration than the ROD group (rhodamine B) in slice $1(\mathrm{p}<0.05)$, but this difference was not detected in slice $2(p>0.05)$. An overall analysis (considering slices 1 and 2) showed that the ROD group presented the highest diffusibility in dentin.

\section{DISCUSSION}

Even though it is a recently developed material, MTA has been extensively studied and several of these studies have demonstrated its superior apical sealing in relation to the other materials used $^{25,27}$. Few studies evaluating dyes have been 
Vogt BF, Xavier CB, Demarco FF, Padilha MS. Dentin penetrability evaluation of three different dyes in root-end cavities filled with mineral trioxide aggregate (MTA). Braz Oral Res 2006;20(2):132-6.

performed concerning this material, which emphasizes the relevance of this study.

According to Aqrabawi ${ }^{2}$ (2000), the dye penetration tests are an easy and useful method to evaluate root-end filling materials because, if the materials are able to prevent the leakage of small molecules (tracer solutions), they should prevent the infiltration of bigger substances, such as bacteria and their by-products.

A controversial topic in the literature is the moment at which the specimens should be immersed in the dye solution ${ }^{15}$. In the present study, immediate immersion was selected based on the fact that in the clinical situation the root-end material will be in contact with secretions, like blood, soon after their insertion in the cavities. Moreover, in the presence of humidity, MTA will suffer expansion, improving the marginal sealing, which could be one of the reasons for the best performance of MTA when compared to other materials ${ }^{24}$.

The dye penetration could be evaluated using qualitative or quantitative methods ${ }^{16}$. In this study, a quantitative analysis was employed, using digitized images and software measurement, allowing the use of a parametric statistical analysis ${ }^{5}$.

The different tracer solutions used in this study demonstrated differences in their penetration capacity (dentinal diffusibility). The overall analysis of the leakage values showed the highest penetrability for rhodamine and the lowest diffusibility for silver nitrate, while methylene blue presented intermediate results. Some reasons could be highlighted to justify these findings.

The acid $\mathrm{pH}$ of methylene blue may result in a possible reaction with dentin and be converted into leukomethylene, a resulting substance that presents an altered tonality of the dye making it difficult to be visualized. The $\mathrm{pH}$ solution varying from 1 to 5 may lead to mineral loss in the apical region, when compared to a neutral $\mathrm{pH}^{20}$. To avoid such problem in this study, methylene blue with $\mathrm{pH} 7$ was used.

According to Wu et al. ${ }^{27}$ (1998), MTA provokes a $73 \%$ reduction in the optical density of methylene blue, which can cause false results in microleakage studies. The reduction of the staining capacity of methylene blue in contact with MTA may have occurred in this study, reducing the observed dye penetration. Such adverse effect should be considered while selecting a tracer solution, and methylene blue should be avoided when using MTA as the root-end material.
Rhodamine B presented more penetrability in apical dentin and such finding could be related to the greater facility of visualization when compared to methylene blue ${ }^{9}$. Corroborative results were found by Hamaoka, Moura ${ }^{10}$ (1996) and Souza $^{19}$ (2004). When comparing several tracer solutions in the apical region, they observed that rhodamine demonstrated higher leakage. According to Tanomaru Filho et al. ${ }^{21}$ (2005), rhodamine is the most appropriate tracer solution to evaluate the sealing capability of MTA; however, it has been used in a few studies when compared to other dye solutions. Another aspect to be considered is that after concluding the apical preparation, if there is gutta-percha or endodontic cement remnants, microleakage may be increased ${ }^{6}$. When observing the slices of all groups, the presence of these remnants was more frequently observed in those specimens from the ROD group.

Although silver nitrate has a smaller molecular weight when compared to rodhamine and methylene blue, it demonstrated the lowest penetrability in dentin in the present study. In this study, it was possible to detect the penetration of silver nitrate into the root-end filling (MTA). Similarly, Xavier et al. ${ }^{29}$ (2005) observed the presence of silver inside the MTA using SEM analysis. It could be hypothesized that some kind of chemical reaction may have taken place between the dye and the material.

Although dye penetration tests are an easy to perform and low-cost method to evaluate the sealing ability of dental materials, several criticisms have arisen in relation to these tests because of the innumerous different methodological approaches that may be used, making the comparison of results between different studies difficult ${ }^{16}$. The findings of this study demonstrated that the tracer solution is another topic to be considered, since the dye solutions investigated showed different penetration capacities in apical dentin, which could influence the results of microleakage tests.

\section{CONCLUSION}

Within the limitations of the methodology applied, it was possible to conclude that the dyes tested presented different degrees of penetration into apical dentin. The lowest leakage results were observed for silver nitrate and the highest penetration, for rhodamine. Methylene presented intermediate results. 
Vogt BF, Xavier CB, Demarco FF, Padilha MS. Dentin penetrability evaluation of three different dyes in root-end cavities filled with mineral trioxide aggregate (MTA). Braz Oral Res 2006;20(2):132-6.

\section{REFERENCES}

1. al-Ajam AD, McGregor AJ. Comparison of the sealing capabilities of Ketac-Silver and Extra High Copper Alloy Amalgam when used as retrograde root canal filling. J Endod 1993;19:353-6.

2. Aqrabawi J. Sealing ability of amalgam, super EBA cement, and MTA when used as retrograde filling materials. Br Dent J 2000;188:266-8.

3. Azoubel E, Veeck EB. Análise do vedamento apical em dentes monorradiculares submetidos à obturação retrógrada e irradiação com laser Nd:Yag. Rev Fac Odontol Univ Fed Bahia 1998;17:25-35.

4. Barthel CR, Moshonov J, Shuping G, Orstavik D. Bacterial leakage versus dye leakage in obturated root canals. J Endod 1999;32:370-5.

5. Cenci MS, Demarco FF, Carvalho RM. Class II composite resin restorations with two polymerization techniques: relationship between microtensile bond strength and marginal leakage. J Dent 2005;33:603-10.

6. Fogel HM, Peikoff MD. Microleakage of root-end filling materials. J Endod 2001;27:456-8.

7. Gerhards F, Wagner W. Sealing ability of five different retrograde filling materials. J Endod 1996;22:463-6.

8. Gorman MC, Steiman HR, Gartner AH. Scanning electron microscopic evaluation of root-end preparations. J Endod 1995;21:113-7.

9. Grempel M, Antoniazzi JH, Paiva JG. Determinação da permeabilidade dentinária radicular natural de dentes humanos anteriores, segundo a faixa etária e o tipo de corante utilizado. Rev Paul Odontol 1990;12:4-14.

10. Hamaoka L, Moura AAM. Avaliação in vitro da permeabilidade dentinária radicular, tendo como fonte de variação três diferentes tipos de corantes. Rev Odontol Univ São Paulo 1996;10:39-42.

11. Ichesco WR, Ellison RL, Corcoran JF, Krause DC. A spectrophotometric analysis of dentinal leakage in the resected root. J Endod 1991;17:503-7.

12. Kidd EAM. Microleakage: a review. J Dent 1976;4:199204.

13. O'Connor RP, Hutter JW, Roahen JO. Leakage of amalgam and Super-EBA root-end fillings using two preparation techniques and surgical microscopy. J Endod 1995;21:748.

14. Pereira CL, Cenci MS, Demarco FF. Sealing ability of MTA, Super EBA, Vitremer and amalgam as root-end filling materials. Pesqui Odontol Bras 2004;18:317-21.
15. Pollard BK, Weller RN, Kulild JC. A standardized technique for linear dye leakage studies: immediate versus delayed immersion times. Int Endod J 1990;23:250-3.

16. Raskin A, D'Hoore W, Gonthier S, Degrange M, Déjou J. Reliability of in vitro microleakage tests: a literature review. J Adhes Dent 2001;3:295-308.

17. Reeh ES, Combe EC. New core and sealer materials for root canal obturation and retrofilling. J Endod 2002;28:520-3.

18. Sano H, Takatsu T, Ciucchi B, Horner JA, Matthews WG, Pashley DH. Nanoleakage: Leakage within the hybrid layer. Oper Dent 1995;20:18-25.

19. Souza EM. Influência dos corantes azul de metileno a $2 \%$ e Rodamina B a $2 \%$ na determinação da capacidade seladora apical de diferentes cimentos endodônticos [Dissertação de Mestrado]. Araraquara: Faculdade de Odontologia de Araraquara da UNESP; 2004.

20. Starkey DL, Anderson RW, Pashley DH. An evaluation of the effect of methylene blue dye $\mathrm{pH}$ on apical leakage. J Endod 1993;19:435-9.

21. Tanomaru Filho M, Figueiredo FA, Tanomaru JMG. Effect of different dye solutions on the evaluation of the sealing ability of mineral trioxide aggregate. Braz Oral Res 2005; 19:119-22.

22. Torabinejad M, Higa RK, McKendry DJ, Pitt Ford TR. Dye leakage of four root end filling materials: effects of blood contamination. J Endod 1994;20:159-63.

23. Torabinejad M, Hong CU, McDonald F, Pitt Ford TR. Physical and chemical properties of a new root-end filling material. J Endod 1995;21:349-53.

24. Torabinejad M, Pitt Ford TR. Root end filling materials: a review. Endod Dent Traumatol 1996;12:161-78.

25. Torabinejad M, Watson TF, Pitt Ford TR. Sealing ability of a mineral trioxide aggregate when used as a root end filling material. J Endod 1993;19:591-5.

26. Vertucci FJ, Beatty RG. Apical leakage associated with retrofilling techniques: a dye study. J Endod 1986;12:3316.

27. Wu MK, Kontakiotis EG, Wesselink PR. Decoloration of $1 \%$ methylene blue solution in contact with dental filling materials. J Dent 1998;26:585-9.

28. Wu MK, Wesselink PR. Endodontic leakage studies reconsidered. Part I. Methodology, application and relevance. Int Endod J 1993;26:37-43.

29. Xavier CB, Weismann R, Oliveira MG, Demarco FF, Pozza DH. Root-end filling materials: apical microleakage and marginal adaptation. J Endod 2005;31:539-42. 